\title{
Diabetes Mellitus and Allopathic Medication Increase the Risk of Cancer Malignancy, but no Side Effect Associated with the Use of Antidiabetic Herbal Medicine
}

\author{
Sanjeev Kumar ${ }^{1 *}$, Kumari Shachi ${ }^{2}$ and Nayan Kumar Prasad ${ }^{3}$ \\ ${ }^{1}$ Department of Zoology, BM College, L N. Mithila University, India \\ ${ }^{2}$ Department of Zoology, K.S.College, L.N.Mithila University, India \\ ${ }^{3}$ Department of Zoology, Tribhvuan University RRM Campus, Nepal \\ Submission: June 25, 2020; Published: July 28, 2020 \\ *Corresponding author: Sanjeev Kumar, Department of Zoology, BM College, LN Mithila University, India
}

\begin{abstract}
Diabetes and cancer are most prevalent disease. Worldwide diabetes is the 4th leading cause of death in the most developed countries. Diabetes is a most common disease easily order affecting 285 million people throughout the world. From different observational studies suggested that diabetes and their allopathic medicines increase the risk of cancer malignancy. Herbal mediciene like- Diabecon Divyamadhunasanivati, IME-9 Madhurakshak Activ, Diacare reduce the blood glucose and No any side effects associated the use of these herbal drugs. Generally herbal Medicine making wellbeing of Patient and adding quality of life.

Keywords: Cancer; Diabetes; Allopathic medicine; Herbal medicine

Abbreviations: NHL: Non-Hodgkin Lymphoma; UKPDS: UK Prospective Diabetes Study; mTOR: Mammalian Target of Rapamycin; SU: Sulphonylurea; FDA: Food and Drug Administration; TZDs: Thiazolidinediones
\end{abstract}

\section{Introduction}

Diabetes mellitus is a common health issue which has reached epidemic proportions because of increasing rates of this disease worldwide. Type 1 diabetes carries $\sim 20 \%$ risk of cancer, but it has different range of tumor [1]. Type II diabetes carries three of the five leading cause of cancer mortality in the USA - carcinoma of colon, pancreas and breast [2], the risk of colon cancer is $30 \%$, risk of pancreatic cancer is $\sim 50 \%$ and risk of breast cancer is $\sim 20 \%$ [3-5]. From different observational studies, it has been seen that the major number of cancer linked with type II diabetes and also associated with obesity or insulin resistance, it has bear suggesting that some other factors such as glucose play an important role [6].

In relation to cancer diagnosis might exist as an increased detection of cancer in diabetic population mostly in the early stages following diabetes onset. From observational studies, it has been observing that the time varying risk of cancer incidence following diabetes onset suggest that there is substantial degree of detection bias in diabetic population [7]. In some cancer such as colorectal cancer, liver cancer and endometrial, cancer are initially elevated risk decreased but remains elevated in those with diabetes, while for other cancers, such as breast, cervical, lung and ovarian cancers have subsequent risk was same as that observed in the non-diabetics, and for prostate cancer, the risk was subsequently lower in men with diabetes [8].

From different observational studies, it has been found that some cancers of metabolically active organs such as pancreas and liver may induce the onset of diabetes [7]. It is well known fact that insulin resistance, hyperinsulinaemia and elevated level of IGF-1 promote tumor cell growth [9]. It is known that cancer cells express insulin receptors and insulin have mytogenic properties, that's why it has been hypothesized that glucose lowering drugs may be and may not be effects on insulin resistance and levels of circulating insulin, although other mechanism may be kinase signaling pathway [10-13]. One another hypothesis is that the increase risk of cancer and death from cancer in patients with type 


\section{Current Research in Diabetes \& Obesity Journal}

2 diabetes is due to elevated blood glucose level. This hypothesis also suggest that hyperglycemia could be a confounder in the increased risk of cancer outcomes observed with increasing use of exogenous insulin treatment by correcting hyperglycaemia, may have a favorable effect of neoplastic disease [14].

From various epidemiological studies suggest that, there has been an association between diabetes and several type of cancer in various populations. The strength of association between cancer populations and type 2 diabetes depends on the specific cancer site. It is evidence that, there is strongest relationship have been demonstrated for liver [15] and pancreatic [16] cancers. In diabetic women, risk of endometrial cancer appears to be doubled [17]. People with type 2 diabetes, risk of breast [18], colorectal [19], bladder [20], Non Hodgkin lymphoma (NHL) [21] and kidney [22] cancers are about $20-40 \%$ higher in people. Surprisingly, prostate cancer is about $10-20 \%$ less likely in men with type 2 diabetes, which is thought to be due, in part, to the reduced levels of circulating testosterone in men with diabetes [23,24]. From different studies there is no consistent association with lung [25] and ovarian [26] malignancies. In Japan, the gastric cancer, may be increased risk in people with diabetes compared with nondiabetic population [27], but this association is unclear in western population. Does diabetes influence the risk of malignancy?

Diabetes and cancer are prevalent disease whose incidence is increasing globally. The most diagnosed cancer globally is lung/ bronchus, breast and colorectal but the most common cancer deaths are lung, stomach, and liver cancer [28]. Globally many cancer areas are not registered but in 2008 there were 12.4 million new cancer cases diagnosed. The most diagnosed cancer in U.S. is prostate, lung/bronchus and colon/ rectum in man and breast, lung/bronchus, and colon/rectum in women. Between the age of 20-79 years, an estimated 285 million people or $6.6 \%$ have diabetes worldwide [29]. In 2007, diabetes prevalence in U.S. was $10.7 \%$ of parsons aged 20 years and older (23.6 million individuals) with an estimated 1.6 million new cases per year. Type 2 diabetes in the most common form, accounting for $~ 95 \%$ of prevalent cases [30]. Worldwide diabetes is $12^{\text {th }}$ leading cause of death and cancer is the $2^{\text {nd }}$ leading cause of death [31]. In U.S. cancer is $2^{\text {nd }}$ and diabetes are $7^{\text {th }}$ leading cause of death. We know that diabetes and cancer are common disease with tremendous impact on health. Different epidemiological evidences suggest that people with diabetes are at significantly higher risk for many forms of cancer. The type 2 diabetes and cancer share many risk factors but potential biological links between the two diseases are incompletely understood.

It has been seen that some cancer develops more commonly in patients with diabetes especially in type 2 diabetes while prostate cancer occurs less often in men with diabetes. There are some common risk factors that partially link between diabetes and cancer such as- a) Sex: Generally, it has been seen that men are more likely to develop both cancer and type 2 diabetes than women.

b) Diet: The food habit also helps to prevent and treat type 2 diabetes-limited red and processed meat and abundant vegetables; fruits and whole grains are also associated with lower risk for many types of cancer.

c) Weight: Overweight and obese people are more likely to develop cancer than lean people. The association between type 2 diabetes and weight is also well established. While it's clear that losing weight reduces the risk of type 2 diabetes, less is known about whether weight loss combats cancer.

d) Exercise: From different studies it has been proves that regular physical activity lowers the risk of developing several types of cancer. Like 80 minutes of Moderate- intensity exercise per day can reduce the risk for type 2 diabetes by 25 to 36 percent.

e) Smoking: Tobacco smoking is associated with lung and several other types of cancer. It is also a risk factor for type 2 diabetes and some diabetes complications.

The most unfortunate fact is that patients with diabetes are at a higher risk than the general population of developing cancer of the urinary tract, liver, biliary tract, pancreas, colon, endometrium and kidney. Several confounding factors directly associated with clinical diversities of diabetes are varying levels of metabolic controls, duration of diabetes, profiles of anti-diabetic therapy and the presence of complications or co-morbidities. Therefore, it has been shared risk factor in both diseases such as age, sex, ethnicity, alcohol, tobacco, diet, physical activity, obesity and BMI seem to further complicate the relation [32]. Contribution of obesity, diet, physical activity etc are the factors that coexist, influence or even cause the diabetes and have also been shown to independently influence cancer risk. Most of the diabetic patients are obese or overweight centre for disease control \& prevention. From several study it has been found that obese people has been increased cancer risk such as colon, rectum, breast, endometrial, pancreas, kidney, liver, gallbladder and adenocarcinoma of oesophagus [33]. A higher mortatlity rate and worsening prognosis in overweight peoples diagnosed with cancer was also postulated [34], including prostate cancer that seemed to have inverse correlation with diabetes [35]. With the increment of insulin resistance, obesity is known for excess estrogen production which may elevate the risk of estrogen dependent tumors. It has been noted that the weight gain has been shown to increase the risk of female reproductive organs neoplasms, namely, cancers of endometrium, breast and cervix [36]. Diet with high glycemic index and high glycemic load are well established risk factors for type2 diabetes $[37,38]$ and they have been suggested to increase risk of breast [39], pancreatic [40], colorectal and endometrial [41] cancer.

Pankaj Shah, M.D. of the Division of Endocrinology, Diabetes, Metabolism \& Nutrition at Mayo Clinic, says: evidence suggests 


\section{Current Research in Diabetes \& Obesity Journal}

that these two common conditions coexist more often that would be expected to occur by chance. A large cohort studies show that pancreatic, colorectal, breast, hepatobiliary bladder and endometrial cancer occur more frequently in people with type 2 diabetes. Potential reasons behind this association include common causality (shared risk factors), hyperglycemia and other metabolic abnormalities of type 2 diabetes that cause cancer and cancer that cause hyperglycemia. Older age, male sex, obesity, demised physical activity, a diet high in calories and glycemic index, excessive alcohol intake and tobacco smoking are associated with increased risk of diabetes as well as cancer.

\section{Diabetes and their Allopathic Medicines}

The recent investigations of attention to the relationship between cancer and type 2 diabetes and in particular possibility that glucose lowering therapies may be involved in this relationship, has presented a considerable challenge to the clinical and research communities [42] (Johnson et al; 2010). For early detection of cancer, cancer screening programs are common in developed country, it has two important consideration, the very $1^{\text {st }}$ is, the timing of implementations of new cancer screening programs relative to the follow up periods of observational studies and 2nd is the degree of potential biases for or against cancer screening in diabetic populations, and whether any biases extend to users of specific glucose lowering medications within the diabetic population [7]. It has been seen in some cases, glucose lowering therapies have been implicated in modulating the risk of cancer incidence of people with type 2 diabetes, leading to considerable controversy among the clinical community [43].

From different observational studies suggest a protective effect on cancer outcomes for metformin [44-47] and on other hand, exogenous insulin have an association with cancer [45,4749] and also association with insulin analogues [49,50] and sulphonylurea therapies $[45,47,48]$, varying risk have been linked with glitazones, with some studies \& suggesting a reduced risk [51] but it has more recently found that the association between bladder cancer with pioglitazone [52]. In all these observational studies, it is very important to include the entire diabetes drug exposure history of individuals in analysis of cancer incidence [7]. All the evidences of diabetes therapy and risk of cancer is based on epidemiological data. More recently, from different observational studies have been found evaluated cancer risk with different type of insulin $[45,51,53,54]$, fueling speculation of an increased risk of cancer associated with the insulin analogue glargine (A21 Gly, B31 Arg, B32 Arg human insulin), owing to its structural similarities to IGF-1. Glucose like peptide-1 (GLP-1) have also increased risk with thyroid and pancreatic cancers [55].

The observational studies of metformin therapy with experimental cancers in vivo is associated with a decline in both insulin levels and activation of insulin receptors of neoplastic tissue [56] is also consistent with an influence of insulin on cancer growth. That's why the association with glucose lowering drugs may be due to direct and indirect effects on insulin resistance and levels of circulating insulin, although others mechanism may also be involved including, effects on AMP- activated protein kinase (AMPK) signaling pathways [57]. In type 2 diabetics oral glucose lowering agents are used early on in the course of the disease, and insulin is reserved for patients who have not responded to oral agents and continue to have undesirable glycemic control, thus for glucose lowering therapies in type 2 diabetes, there is a selection of patients not responding to oral agents into the insulin treated group [7]. To the extent that non-response is associated with risk factors for cancer, confounding by indication arises [7].

The majority of different observational studies, evidences of an increased or decreased risk is generated through relative comparison of one class of glucose lowering therapy against the others, such as metformin is commonly used by all type 2 diabetics but historical data, prior to 1998-1999 and the publication of the landmark UK prospective diabetes study (UKPDS) results, would have a mix of metformin and sulphonylurea as the 1st line oral therapy [7]. A challenging issue related to counfounding by indication is the absolute level of glycemic control during follow-up period, particularly given that hyperglycemia itself may be contributing to an increase risk of cancer $[58,69]$. Drug use patterns are different in different users; it will arise different health care systems that provide different levels of coverage for different agents. It is a well-known fact that the transformed cells have a high glucose requirement in keeping with their high rates of glycolysis relative to normal cells, as $1^{\text {st }}$ recognized by Otto Warburg [60]. The cancer cells must have high level of glucose uptake and normoglycemic conditions are able to satisfy their glucose requirement [61]. This is a consistent clinical experience view, that cancer can behave aggressively in normoglycemic patients, and with 2-deoxy-2[18F] fluoro-Dglucose positron emission tomography visualization of cancers under normoglycemic condition [62]. Different experimental studies of dose response relationship between glucose concentration and tumor growth generally show that increased level of glucose concertration increase the proliferation, but with a plateau occurring at about $5 \mathrm{~m} \mathrm{~mol} / 1$ glucose [63]. This observational study suggest that hyperglycemia have no growth advantage but normalization of glucose levels by insulin therapy would not be expected to constrain cancer growth. This hypothesis consistently suggests that when variation of energy intake influence tumor growth, it does so via alterations in the hormonal milieu, rather than by directly influencing energy available to cancer cells [60]. Thus, this review is supported by the large observational studies has been demonstrated the very strong relationship between diabetes and their allopathic therapy for cancer risk. This review developing frameworks for the evaluation of methodological aspects linked to diabetes, diabetes treatments and cancer. 


\section{Insulin and Insulin Analog}

Insulin is usually given subcutaneously, either by injection or by an insulin pump. Insulin may also be given intravenously. We know off course that there are three type of insulin, characterized by rate which they are metabolized by the body. It may be divided into rapid acting insulin, intermediate acting insulin, and long acting insulin.

Examples of rapid acting insulin:

a. Insulin lispro (Humalog)

b. Prompt insulin zinc (Semilente, slightly slower acting)

c. Insulin Aspart (Novolog)

d. Insulin glulisine(Apidra)

e. Regular insulin (Humalin R, Novolin R)

Examples of intermediate acting insulins include: -

a) Isophane insulin, neutral protamine Hagedorn (NPH) (Humulin N, Novalin N)

b) Insulin Zinc (Lente)

Examples of long acting insulin include

i. Insulin glargine (Lantus)

ii. Insulin detemir (levemir)

iii. Extended insulin Zinc insulin (ultralente)

Doctor's prescribed insulin and insulin analog mostly with type 1 diabetics and also with type 2 diabetic for treatment of hyperglycemia in part due the progressive loss of $\beta$-cell function over time, approx $40-80 \%$ of individuals with type- 2 diabetes will ultimately be considered for insulin therapy in an effort to achieve glycemic targets [61]. Several formulations of insulin exist: short-acting human regular insulin, intermediate acting human NPH insulin and both rapid and long acting analog of human insulin (David et al; 2010). It is a well-known fact that the insulin injection significantly increases high levels of circulating insulin in the systemic circulation than endogenous insulin secretion, that's why a possible links between hyperinsulinemia and cancer risk. From different epidemiological evidence support strong associations between both increased circulating insulin and increased C-peptide and cancer incidence [62-65]. More recently according a epidemiological data, there is a possible correlation between long term insulin and insulin analog use and associated with increased risk of cancer $[45,49,53,54]$.

The possible association between insulin and cancer has always attract researchers for research interest, since cancer of breast, colon and pancreas have all been associated with increased circulating levels of endogenous insulin in the non-diabetic population $[6,66]$. This hypothesis might explain some of overlap between cancer risk in diabetes, obesity and other conditions associated with insulin résistance [6]. These epidemiological studies findings the possible mechanistic basis, in that insulin is a growth factor for a number of epithelial tumors in cell culture system and hyperinsulemia also produces a secondary increase in the availability of IGF-1 another known tumor growth factor - which is mediated by a reduction in IGF binding protein-1 levels (IGFBP-1), these changes in the insulin IGF-1 axis might be expected to favour the survival and progression of early malignancy $[6,67]$. Before the malignant growth, tumor cells must have six road blocks such as self-sufficiency in growth signals, insensitivity to growth-inhibitory signals, evasion of programmed cell death (apoptosis), limitless replication potential, sustained angiogenesis and loss of barriers to tissue invasion [68]. Insulin glargine (insulin analog) may have a disparate impact on cancer risk through its binding to IGF-1 receptors.

The weekness and potential strength of these studies have been boardly debated and well detailed $[14,43,68]$. Insulin or insulin analogs have potential mechanisms which influence neoplastic disease from direct or indirect actions, direct action can receive most attension or interactions with cancer cells, partially transformed cells or cells at risk for transformation and in indirect action can interact with signaling molecules whose levels or activity are influenced by administered insulin on these target cells.

Randomized epidemiological research has emphasized differences between human insulin and analog insulins with respects to binding affinity to the IGF-1 receptor, including evidence that insulin glargine has much higher affinity, and higher mitogenic potency, than human insulin or other analog [6971]. From different observational studies provides three basic essential backgrounds about insulin therapy and cancer:

a From different epidemiology, it has been finding that insulin concentrations within the physiological or therapeutic range are associated with the rate of tumor diagnosis;

b In laboratory it found that the intrinsic mitogenecity or insulin may vary according to functional plasticity of the insulin IGF-1 signalling network, particularly in tumor cells, and

c The demonstration that some tumor cell lines are responsive to changes in the ambient concentration of either or both these ligands [43].

One concern is that the insulin or analog that retains specificity for the insulin receptor over the IGF-1 receptor is unlikely to have important mitogenic effects or effects on neoplasia may be simplistic in the light of recent research results [72,73], it shows that the insulin receptor is present on neoplastic cells and may itself influence neoplastic behavior in certain context. It is concerning that the insulin analogues might be associated with an increased risk of tumor progression $[74,75]$. The biosynthesis of human insulin may modified 'designer' insulin for more faster sustained effects of injections, and it soon became apparent that 
some alteration of insulin molecule increased its trophic effects, that demonstrate the accelerated DNA synthesis and cell divisions in cell culture system, typically human mammary epithelial cells (HMECs) [43]. These all process are happend due to increased reactivity with the IGF-1 receptors [76,77] and in the course of preclinical evaluation all new insulin's routinely screened.

The insulin analogs, insulin B10Asp is sufficient to produce a tenfold increase in mitogenicity, compared to human insulin, in the light of this research, the regulatory authorities required 2 year carcinogenicity studies in rodents, as against the standard 1year toxicity testing, and the insulin was withdrawn when mammary tumors appeared in rats [78]. In this experiment find that the insulin and IGF - 1 receptors recognize the terminal part of the insulin $\beta$ chain and extensions into the $C$ chain differently, with the modification of B26-B30 regions of the B chain increases IGF-1 receptor binding as does modification of the $\mathrm{B} 10$ residue [79]. In both chains have additive effects in that AspB1DI Arg insulin used for experimental purpose only, produces a 90- fold increases in binding to the IGF-1 receptor on HMECs (Smith et al; 2009). Insulin glargine (A21 Gly, B31 Arg, B32 Arg human insulin) also have arginine residues at positions B31 and B32 together with a glycine substitution at A21; insulin as part (B28 Asp human insulin) carries a B28 Asp substitution, and in insulin lispro (B28 Lys, B29 Pro human insulin) the sequence of proline and lysine residues at B28/B29 in human insulin as reversed [43]. The insulin detemir, B29 Lys (E-tetradecanoyl), des B30 is the human insulin carries a fatty acyl chain attached to the end of B chain [43]. The insulin analogues have ability to stimulate HMEC growth generally correlates with their ability to bind the IGF-1 receptor, but prolonged interaction with either receptor also appears necessary for stimulation of mitotic activity [76].

As discussed in previous section, insulin analogues have been tested in tumor cell lines with variable results [43]. From different studies it has been find that the pancreatic cancer cell line responded similarly to insulin glargine and human insulin and survival of insulin glargine treated patients following treatment for pancreatic cancer did not differ from that of patients of insulin or controls [80]. In recent study, colorectal, breast and prostate cell lines showed proliferative changes and increased resistence to apoptosis in response to exposure to pharmacological doses of insulin glargine, insulin determir and insulin lispro, but not to human insulin [81]. Different observations suggest that insulin glargine is partially degraded at the injection site, forming two bioactive products such as M1 which lacks the diarginine residues at B31 and B32 and M2, which has additional deletion of the threonine at B30, these both products are glycine substitution for asparagines at A21, which is closely similar to human insulin $[82,83]$ and their mitogenicity appears to be low [83], all three forms enter the circulation and the further degradation of insulin glargine to M1 occurs on exposure to serum, probably mediated by carboxypeptidese enzyme [83]. In summary, the mandatory preclinical testing procedures to which all the insulin analogues in current clinical use have been subjected are therefore insufficient to confirm or exclude a possible cancer risk in humans [43].

Random clinical trial data from an open-label-5-year trial of insulin glargine versus NPH insulin did not find evidence of excess cancer risk (all sites combined) in the insulin glargine [84], although among the $\sim 10000$ subjects randomized, there was a very small number of cancer end points ( 57 cases of cancer in glargine arm and 62 cases of cancer found in NPH arm). According to (The ORIGIN Trial; 2010) the glargine versus placebo in patients with impaired fasting glucose or newly diagnosed type 2 diabetes is much larger (approx. 12000 patients randomized and followed for 6-7 years). From this random clinical trial data, the most important fact of cardiovascular outcomes and may still not provide definitive evidence regarding cancer incidence, especially for specific cancers.

\section{Metformin}

Metformin, a biguanide is most used for type 2 diabetes in children and teenagers. In all common diabetic drugs, metformin is the only widely used oral drug that does not cause weight gain. Metformin reduces approx. 1.5-2\% value of glyceted hemoglobin (A1C).

Some commonly used metformin and their actions-

a. Buformin also was withdrawn due to lactic acidosis risk [85].

b. Metformin (Glucophage), it is the best choice for patients who also have heart failure, but it shows the discontinued before any radiographic procedure involving intravenous iodinated contrast, as patients are at an increased risk of lactic acidosis [86].

c. Phenformin (DBI) was used from 1960s through 1980s, but was withdrawn due to lactic acidosis risk [87].

Metformin is the first line medicine for treatment of type2 diabetes. It is generally prescribed at int].ial diagnosis in conjuction with exercise and weight loss, as opposed to in the past, where it was prescribed after diet and exercise had failed. There is an immediate release as well as an extended release formulation, typically reserved for patients experiencing GI side-effects. The initial or combination therapy in patients with type 2 diabetes most commonly prescribed biguanide metformin [88]. The action mechanism of metformin in diabetics is not totally understood, the level of insulin and circulating glucose or reduces in patients with insulin resistance and hyperinsulemia by metformin treatment, the primary mode of action is through reduced hepatic glucose output [89].

In different studies it has been find that, metformin inhibits the cell proliferation, reduce colony formation, and cause partial cell cycle arrest in cancer cell lines [10,90]. According to Algire et al, [91] from different observational studies it has been shown that 
metformin induced growth inhibition of experimental cancers in vivo is associated with a decline in both insulin levels and activation of insulin receptors of neoplastic tissue is also consistent with an influence of insulin on cancer growth. It is not clear; however, the entire diabetes drug exposure has cancer incidence. In the majority of the available observational studies, metformin is currently the 1st line therapy for all patients with type 2 diabetes, but historical data, prior to 1998-1999 and the publication of the landmark UK Prospective Diabetes Study (UKPDS) results, would have a mixure of metformin and sulphonylurea as the 1 st line oral therapies [7].

The antitumor effect seen in metformin user that mediated via its ability to increase the AMP- activated protein kinase (AMPK) signaling pathway [10]. Rise in the AMP: ATP ratio activate the AMPK, which plays the key role in cellular energy balance, switching on ATP - generating pathways and switching off ATP - consuming pathways activation restores levels of ATP and this enzyme is thought to mediate many of metabolic actions of metformin [92]. The increased level of AMPK also inhibits the downstream mammalian target of rapamycin (mTOR) complex; these mTOR kinase integrates the various cellular signals, from growth factors, nutrition and energy state to regulate protein synthesis and cell growth [43]. The inhibitor of mTOR is rapamycin and its derivative have been tested in several cancer trails and find success with some aspects, a study of human prostate cancer cells demonstrated a strong anti-proliferative effect of metformin [93]. This all effects in AMPK pathways seen unaffected but it was associated with cell cycle arrest in Go/G1 phase, together with a major reduction in cyclin D1 levels [43]. Different studies suggest that metformin- induced activation of AMP- activated protein kinase (AMPK) in tumor cells may lead to growth inhibition at least in part by inhibiting protein synthesis [94].

From in vivo studies one interesting fact is the metformin show less neoplastic activity when its metformin used on a control diet mouse than metformin used on high diet mice it show hyperinsulinemia and accelerated tumor growth [91]. This vivo study suggest that the insulin lowering action of metformin may contribute to its anti-neoplastic activity, and that it may have less impact on cancer in less hyperinsulinemic patients. One other invitro study finds that metformin may have to kill selective cancer stem cells and enhance effectiveness of breast cancer treatment [95-97]. In rodents models, metformin shown to reduce mammary tumor growth [98]. Different non-random study of diabetes drug therapy in clinical trials, metformin acts to improve sensitivity and has been associated with a reduction in fatal and non-fatal myocardial infarctions in overweight individuals [99] and this is commonly prescribed in overweight individuals, who in turn are at increased risk of many cancers. It is might except that the risk of cancer increased in patients starting on metformin therapy but, incontrary, according to [45,100-102] metformin has been consistently associated with a reduced risk of cancer. The reduced risk of cancer in metformin user consistently finds in that the increased risk of malignancy in metformin users are generally overweight or obese. The most surprising fact with metformin use is lower risk with some types of cancer. The metformin uses in type 2 diabetics have increased risk with colorectal cancer [47].

According to Genevra Pittman [103] one in nine people with pancreatic cancer has a prior diagnosis of diabetes and metformin cause the body to make or absorb less glucose. According to a medical report [103] approx. two percent of people with pancreatic cancer had been taking long term metformin. The increasing number of observational human studies suggest that treatment with metformin is associated with reduced risk of cancer $[45,98,104-106]$ or cancer mortality [107].

\section{Sulphonylurea}

Sulphonylurea is widely used oral anti-hyperglycemic medications. It is insulin secretogogues, triggering insulin release by inhibiting the K-ATP channel of the pancreatic beta cells. Eight types of these pills have been marketed in North America, but not all remain available. The "second generation" drugs are is more used in comparison to " 1 st $g$ generation" drugs because it is more effective than 1st generation and have fewer side effects. It may cause weight gain. From the study of 2012, it found that sulphonylurea raise risk of death compared with metformin [108].

Name of $1^{\text {st }}$ and $2^{\text {nd }}$ generation sulphonylureas

$1^{\text {st }}$ generation sulphonylureas

a. Tolbutamide (orinase brand name)

b. Acetohexamide (Dymelor)

c. Tolazamide (Tolinase)

d. Chlorpropamide (Diabinese)

$2^{\text {nd }}$ generation sulphonylureas

a. Glipizide (Glucotral)

b. Glyburide or Glibenclamide (Diabeta, Micronase, Glynase)

c. Glimeperide (Amaryl)

d. Gliclazide (Amaryl)

e. Glycopyramide

f. Gliquidone

From different studies it has been found the increased risk of cancer in type 2 diabetes. Patients which have type 2 diabetes exposed to sulphonylureas have a significant increased risk of cancer- related mortality. It is uncertain whether this increased risk is related to a deleterious effect of sulphonylurea or due to some unmeasured effect related to choose of therapy and cancer risk [109]. The risk of mortality from solid tumors is higher in 
sulphonylureas user. The long-term used of the diabetes drug sulphonylureas has been found to be associated with a lower risk of pancreatic cancer-but only in women according to new research published in the American journal of Gastroenterology.

When we see the general practice research database of UK, more than eight people in the UK including 2800 who had been diagnosed with pancreatic cancer between 1995 and 2000. Then scientist looked again how many people previously diagnosed with diabetes and which anti- diabetic drug they had be prescribed - such as sulphonylureas, which cause the body to make more insulin to regulate blood sugar levels. The researchers found that the long terms use of sulphonylureas ( $>30$ prescriptions) are materially increased risk of pancreatic cancer. Sulphonylureas users accounted for just over $3 \%$ of people with a new pancreatic cancer diagnosis and $2 \%$ without cancer [110].

When we see the research study of Bowker et al, [110], it was a population - based cohort study using administrative databases Saskatchewan Health. In this research they identified 10,309 new users of metformin or sulphonylureas with an average follow up of $5.4 \pm 1.9$ years (Mean $\pm \mathrm{SD}$ ). The mean age for the cohort was $63.4 \pm 13.3$ years and $55 \%$ were men cancer mortality over follow up was $4.9 \%$ (162 of 3,340) for sulphonylurea monotherapy users. The mortality rate of, sulphonylurea monotherapy user is high among metformin and insulin user.

From different epidemiological evidences, it have been identified an increased risk of development of cancer in people with type 2 diabetes [4,111-123].

From different observational studies it has been found that sulphonylurea such as glibenclamide is often used for the treatment of type-2 diabetes. These medicines inhibit the ATP driven potassium channels in pancreatic beta cells, pushing $\mathrm{Ca}_{2}+$ to enter the beta cells, including them to release, insulin in a process known as depolarization. Because of this insulin blood glucose levels temporarily fall down, but long term durg exposure eventually fails through an unknown mechanism. According to Maria Remedi and Cdin Nichols from the Washington university school of medicine examined the pancreatic beta cells in mice treated with sulphonylureas. They found that the treatment with sulphonylurea does not cause death of pancreatic cell, but other cause them to be permanently depolarized across the cell's channels.

We now know off course that, the pancreatic $\beta$ - cell ATP sensitive K- ATP channels have a critical link between nutrient metabolism and insulin secretion, maintaining the blood sugars in a narrow physiological range. In the case of fasted animals $\beta$ - cell membraneconductance and cellsgoneto hypolarizationstagethat's why insulin secretion stopped. But in the case of sulphonylurea fed state, glucose metabolism increases the ATP/ADP ratio, closing K-ATP channels , causing membrane depolarization and voltage dependent $\mathrm{ca}_{2}+$ entry, which is turn trigger insulin secretion [124] .In this case K- ATP channels becomes heterochromatic complex that inwardly form $4 \mathrm{~K}+$ channel subunits (Kir6.2) and 4 sulphonylurea (SU) receptors (SUR1) (Nichol C G.,2006) when $\beta$-cell K-ATP channel submit (sur1, ABCCB,OMIM accession number 600509, and kird 2, KCN)110MIM600937., Gen bank , which have loss mutation function which underlie congenital hyperinsulinism (HI ) in humans [125-130], a genetic disease characterized by hyperinsulinemia and hyperglycemia [131]. When $\mathrm{HI}$ reduced or absent $\mathrm{K}$-ATP channel activity is expected to result in consititutive depolarization elevated intracellular $\left(\mathrm{Ca}_{2}+\right)$ and hypersecretion of insulin [132]. With the varying genetic suppression of K-ATP channel activity will lead to enhanced excitability, but with different long - term consequences for insulin secretion, depending on the severity of suppression : incomplete loss of K-ATP channel (eg: in kir 6.2[AAA]) [133] or in heterozygous kir6.2+/0 or SURI +/o mice [134] causes a maintained hyperinsulinism, whereas complete loss (in Kir6.2and Sur1-k0 mice) causes transient hypersecretion that is followed by a secretory deficit and reduced glucose tolerance [135-137]. The KATP channels clearly maintained K-ATP activity because the patients were responsive to K- ATP channel drugs. These drugs try to compensate primary endocrine insensitivity in the peripheral tissue [138].

Tolbutamide and glibenclamide (glyburide) are widely used in type 2 diabetic patient because they induce insulin secretion indepentdently of the metabolic state of the $\beta$-cell [139-141]. The regular use of these antidiabetic drugs bind to the SUR1 subunit , leading to inhibition of K-ATP channel activity, membrane depolarization and insulin secretion, but this failure activity is not understood now , either it related disease or drug effect [142144]. It is also found that the treatment with glibenclamide and tolbulatamide may induce $\mathrm{ca}_{2}+$ dependent $\beta$-cell apoptosis [145]. It is reported that the glibenclamide treated minimum 6 cells showed a reversible reduction in insulin content and accerelerate apoptotic $\beta$-cell death [146-148] apoptosis is specially enhanced only by expression of the receptor sur1 but not SUR2B , in HEK 293 cells [149]. The dysfunction of pancreatic $\beta$ - cell causes pancreatic cancer in diabetics. CA19-9 is a tumor associated antigen that was originally defined by a monoclonal antibody produced by hybridoma that prepared from urine spleen cells immunized with a human colorectal cancer cell line and the increased level of CA19-9 also shown to increase in any maligrant disease such as upper gastrointestinal tract drain and hepatocellular and colorectal cancer [150].

\section{Thiazolidinediones}

Thiazolidinediones (TZDs) is also called "glitazones" it binds to PPAR $\gamma$, it is a type of nuclear regulatory protein that involve in transcription of genes regulating glucose and fat metabolism. Its generic brand name is pioglitazone, Actos, rosiglitazone. 


\section{Current Research in Diabetes \& Obesity Journal}

These medicines lower insulin resistance on muscle and fat. It also reduces glucose that produced by the liver. The PPARS acts on peroxysome proliferators responsive elements (PPRE) (http:// www.Healthvalue.net/ diabetes insulin PPAR.html). The insulin sensitive genes are influenced by PPREs that enhance the production of m- RNAs of insulin dependent enzymes that finally use the glucose by the cells in very better way there have been some contradiction of use of TZDs in selected patients like those with liver disease and untreated and unstable heart failure, TZDs are usually used when other medicines have failed to lower blood sugar levels into a target range. It decrease triglycerides and raise the HDL cholesterol. Diabetic medicines are work best on that type people who are being active and getting healthy foods. From different studies it has been proved that TZDs can lower Hb A1C by $0.5 \%$ to $1.4 \%$ [151]. Every medicines that you take regularly have some side effects, it have also some minor and major side effects also like weight gain retention of fluid in the body that may causes heart failure, muscle pain, runny or stuffy nose, sore, throat headaches. According to a survey the breaking news about TZDs is, it again begins menstruation cycle in those women who have stopped menstruation and they again become pregnant because they take TZDs pills. According to a warning from the US Food and Drug Administration (FDA) [152], these drugs may increase risk for upper arm or foot fractures. Some studies have shown that people who take actos may raise their chance of bladder cancer.

The FDA warns on June 2011, if you use actos more than one year may be associated with an increased risk of bladder cancer. The FDA says that people who have bladder cancer should not take actos and actos should be used with caution in people with history of bladder cancer. This warning also applies to the combination diabetes pills containing Pioglitazone Actoplus Met, Actoplus Met $\mathrm{XR}$, and Duetact.

The definite human data on cancer risk associated with TZDs are not available at new but there are three epidemiological studies conducted among patient with diabetes focused on all cancers combined or only on limited no. of cancer sites and result were inconsistent [152-154]. According to one cohort study, short term use of pioglitazone was not associated with increased risk of bladder cancer, but more than 2 years was weakly associated with increased risk. The FDA is also aware of a recent epidemiological study conducted in France, which suggests an increased risk of bladder cancer with pioglitazone. The PPAR - isoform is most abundantly expressed in adipose tissue and immune cells and plays an important role in adipicyte differentiation and lipogenesis [155], the anti - diabetic drug TZDs improves glucose homeostasis and insulin action in type 2 diabetes [156-158] and may prevent the progression from impaired glucose tolerance to type 2dibetes [159] ( Buchanan et al; 2002) . The treatment with TZDs alters the expression of metabolically important genes in adipose tissue liver and muscle as demonstrated both in insulin resistant animal model $[160,161]$ and in some cell culture systems [162,163]. In adipose tissue, TZDs have been shown to alter expression of leptin, inflammatory molecules and circulatory proteins such as tumor necrosis factor, which may be implicated in systemic insulin resistance. It remains to be determined whether altered expression of these key metabolic genes accompanies the insulin sensitizing effects of TZDs in humans.

On June 2011 Germany's Federal Institute for Drugs and Medical Devices also advised doctors not to prescribe the medication until further investigation of the cancer risk had been conducted. On June, 2011the US FDA announced that pioglitazone use for more than one year ma.y be associated with an increased risk of bladder cancer, and that the information about this risk will be added to warning and precautions section of the label for pioglitazone containing medicines. The patient's medication guide for these medicines will also be revised to include information on the risk of bladder cancer. The short-term use of pioglitazone was not associated with an increased incidence of cancer. Peroxisome proliferator activated receptor [PPAR] $\gamma$ has been detected in normal uroepithelial tissue by some but not all investors and is generally detactable in bladder tumors [164166]. Thiazolidinedione (TZD) PPAR $\gamma$ ligands have been shown to alter cell proliferation rates and differentiation in human cancer cell lines, including bladder cancer cell [164-170]. In preclinical studies it has been found that male rats treated with pioglitazone developed more bladder tumors than male rats treated with placebo. This result was not found in female rats [171].

A new study of Indian researchers revealed that a popular class of diabetes drugs increases risk of bladder cancer. Researcher from the Perelman School of Medicine at the University of pennsylvania found that patients taking thiazolidinedione (TZDs) drugs which account for upto $20 \%$ of the drugs prescribed to diabetics the United States - are two to three times more likely to Develop bladder cancer than those who took a sulphonylurea drug, another common class of medications for diabetics.

\section{Natural plant products to care diabetes and cancer}

The natural plant products have been used as secondary metabolite as a natural defense mechanism against disease and infection The plant and plant products have played a pivotal role in the health care of many culture, both ancients and modern [172-176]. The Indian system of holistic medicine known as "ayurveda" used mainly plant based drugs and formation to treat various ailments, including diabetes and cancer. Herb and spices not only contain many phytonutrients but have many amazing medicinal and health-giving properties. Many have been used for thousands of years to care adverse human conditions, infections, and disease without serious side effects that modern day drugs provide because they work with the body naturally as mature intended. Ancient Indian Health Care System bases on herbs and diet. For health and disease cure ayurveda sees in holistic terms. The ayurveda not believed to just treatment of disease but also effects the individual of a whole. It emphasizes on harmony of mind, spirit, and body to cure disease. 


\section{Current Research in Diabetes \& Obesity Journal}

The use of herbs and spice revolves around a preventive measure more than curative one. It is the correct way to living life. An herbal medicine does not claim a care to cancer and diabetes. All it can do such cases is to prepare the person and to make it as comfortable as possible. So, it is not one to claim miracles. There are many doctors in allopathic branch of medicine, who after a certain point to tell their patients that they have stretched their limits and that they should opt for Ayurveda. Common herbs and spices may help protect against certain chronic conditions such as cancer, diabetes and heart disease

Herbs including basil and parsley are from plants and plant parts. Spices often come from the seeds, berries, bark or roots of plants. Certain herbs and spices curb inflammation in the body, which may give rise heart disease and cancer. For example, antioxidants in cinnamon have been linked to lower inflammation, as well as reduction in blood glucose concentrations in people with diabetes polyphenols a type of plant compound provide one of the main health benefits associated with herbs and spices.
David Heber, MD, PhD, professor of medicine and director of the UCLA Center for Human Nutrition say that different herbs and spices offer health benefits. Most of the evidence exists for cinnamon, chili peppers, turmeric, garlic, oregono, basil, thyme and rosemary. Currently there has been on augmented interest globally to identify compound isolated from natural products that are pharmacologically effective and have low or no side effects for use preventive medicine and the food industry.

Most welcome thing in the field of herbal medicines we see that in last few years there has been an exponential growth and these drugs are gaining popularity both in developed and developing countries. According to WHO about 21000 plants are used for medicinal purpose around the world [177]. Among these 2500 species [177] are in India out of which 150 species are used commercially on large scale. So, we know that India is the largest producer of herbal medicines and we say it "botanical garden of the world" These herbal medicines are used as anti-diabetic and anti-cancerous activity such as (Table $1 \& 2$ )

Table 1: Medicinal Plants with anti-diabetic and anticancerous properties.

\begin{tabular}{|c|c|c|c|c|}
\hline S..No & Common Name & Botanical Name & Family & Uses \\
\hline 1 & Methi & Trigonella foenum gracecum & Fabaceae & Seeds \\
\hline 2 & Fern & Nephoelepsis tuberose & Oleandraceae & Bulb \\
\hline 3 & Keukand & Costus specious & Costaceae & Rhizome \\
\hline 4 & Indian wheat & Plantago ovata & Plantaginaceae & Husk \\
\hline 5 & Garlic & Allium sativum & Alliaceae & Bulb \\
\hline 6 & Indian sarsaparilla & Hemidesmus indicus & Asclepiadaceae & Root \\
\hline 7 & Onion & Allium сера & Lilliaceae & Bulb \\
\hline 8 & Pinyn & Acontum carmichaeli & Ranunculaceae & Root \\
\hline 9 & Chilli peper & Capsicum annum & Solanaceae & Fruit \\
\hline 10 & Goat'srue & Galega officinalis & Fabaceae & Seed \\
\hline 12 & Sea Pea & Lathyrus japonica & Fabaceae & Seed \\
\hline 13 & Rice & Oriza sativum & Poaceae & Root \\
\hline 14 & Guduchi & Tinospora cardifolia & Menispermaceae & Plant \\
\hline 15 & Bitter gourd & Momordica charantia & Cucurbitaceae & Fruit \\
\hline 16 & Indian Kenotree & Pterocarpus marsupium & Fabaceae & Bark \\
\hline 17 & Ginger & Zingiber officinale & Zingiberaceae & Rhizome \\
\hline 18 & Gower plant & Cyamopsis tetraonolobous & Fabaceae & Fruit \\
\hline 19 & Phalsa & Grewia asiatica & Malvaceae & Fruit \\
\hline 20 & Indian Gum Arabic & Acacia arabica & Laguminosae & Seeds \\
\hline 21 & Holy Fruit Tree & Aegle marmelos & Rutaceae & Root bark \\
\hline 24 & Sugarapple & Annona squamosa & Annonaceae & Leaf \\
\hline 25 & King of bitter & Andrographis paniculata & Acanthaceae & Plant \\
\hline 26 & Neem & Azadirachta indica & Meliaceae & Plant \\
\hline
\end{tabular}




\section{Current Research in Diabetes \& Obesity Journal}

\begin{tabular}{|c|c|c|c|c|}
\hline 27 & Life plant & Biophytum sensitivum & Oxalidaceae & Leaf \\
\hline 28 & Tarvine & Boerhavia diffusa & Nyctaginaceae & Aqueous leaf \\
\hline 29 & Tanner's cassia & Cassia auriculata & Leguminoseae & Leaf \\
\hline 30 & Ivygourd & Coccinia indica & Cucurbitaceae & Leaf \\
\hline 31 & Carilla fruit & Casearia esculenta & Flacoutlaceae & Root \\
\hline 32 & Madagascarperi winkle & Catharanthus roseas & Apocynaceae & Leaf \\
\hline 33 & Green tea & Camellia sinensis & Theaceae & Leaf \\
\hline 24 & Indian Blackberry & Eugenia jambolona & Myrtaceae & Pulp \\
\hline 35 & Mango & Mangifera indica & Anacardiacea & Leaf \\
\hline 36 & Holy basil & Ocimum sanctum & Lamiaceae & Leaf \\
\hline 37 & Pomegranate & Punica granatum & Punicaceae & Flower \\
\hline 38 & Indian gentian & Swertia chirayita & Gentianaceae & Plant \\
\hline 39 & Arjuno bark & Terminalia arjuna & Compertaceae & Bark \\
\hline 40 & Kalmegh & Andrographis paniculata & Acunthacae & Leaves \\
\hline 41 & Vinca & Catharanthus roseus & Apocynacae & Whole \\
\hline 42 & Nichinda & Vitex trifolia & Verbanaceae & Leaf \\
\hline 43 & Indian Ipeacac & Tylopora indica & Asclepiadaceae & Root \\
\hline 44 & Tobacco & Ticotiana tabacum & Solanaceae & Leaf \\
\hline 45 & Mint & Mimosa pudica & Mimosaceae & Plant \\
\hline 46 & Danti & Jatropha cureas & Euphorbiaceae & Leaves, Seeds, oils \\
\hline 47 & Carrot & Daccus carota & Apiaceae & Root \\
\hline 48 & emon & Citrus medica & Rutaceae & Root \\
\hline 49 & Senna & Cassia senna & Caesalpinaceae & Leaves \\
\hline 50 & Tarwar & Cassia ouriculata & Caesalpinaceae & Root \\
\hline 51 & Orchid tree & Bauhinia variegata & Caesalpinaceae & Root \\
\hline 52 & Palash & Butea monosperma & Fabaceae & Bark \\
\hline 53 & Arhar dal & Cajanus cajan & Fabaceae & Leaves \\
\hline 54 & Bhilwa & Semecarpus anacardium & Anacardiaceae & Fruit \\
\hline 55 & Indian mulberry & Morinda citrifalia & Rubiaceae & Fruit \\
\hline 56 & Beer berry & Vaccinium stamineum & Ericaceae & Fruit \\
\hline 57 & Turmeric & Curcuma longa & Zingibaracae & Rhizome \\
\hline 58 & Orchrosia & Ochrosia elliptica & Apocynaea & Trunk bark \\
\hline 59 & May Aabble & Podophyllum paltatum & Berbeidacae & Rhizome \\
\hline 60 & Fig & Ficus glomerata & Moraceae & Leaf, Bark \\
\hline 61 & Periwinkle & Vinca rosea & Apocynaceae & Leaf \\
\hline 62 & Tilkore & Coccinia cordifolia & Cucurbitaceae & Leaf \\
\hline 63 & Sweet flag & Acorus calamus & Acoraceae & Rhizome \\
\hline 64 & Kurry leaf & Murraya Keonigii & Rutaceae & Leaf \\
\hline 65 & Coriander & Coriandrum sativum & Apiaceae & Seed, Leaf \\
\hline 66 & Clove & Syzygium aromaticum & Myrtaceae & Oil, Bulb \\
\hline 67 & Cinnamon & Cinmmomum verum & Lauraceae & Bark \\
\hline 68 & Bay leaf & Laurus nobilis & Lauraceae & Leaves \\
\hline 69 & Black papper & Piper nigrum & Piperaceae & Seeds \\
\hline
\end{tabular}




\section{Current Research in Diabetes \& Obesity Journal}

\begin{tabular}{|c|c|c|c|c|}
\hline 70 & Mustard & Brassica Juncea & Brassicaceae & Oil, Seed, Leaf \\
\hline 71 & Cumin & Cuminum cyminum & Apiaceae & Seeds \\
\hline 72 & Fennel & Foeniculum vulgare & Apiaceae & Bulb \\
\hline
\end{tabular}

Table 2: Anti diabetic herbal drugs.

\begin{tabular}{|c|c|c|c|}
\hline 1 & $\begin{array}{l}\text { Divya Madhunashini } \\
\text { Vati }\end{array}$ & Patanjali & $\begin{array}{l}\text { Shilajit (Asphalatum), A shwagandha (Withania-somnifera ), Gulmaar (Gymnea } \\
\text { sylvestre), Nimba (Azadarachatica indica), Harara choti (Terminalia chebula), Giloy } \\
\text { (Tinospora cordifolia), Kutaj (Holarrhena anti dysentrica),Gokhrudana (Tribulns } \\
\text { terrestris) , Bahera (Terminalia belirica), Amala (Amblica officinalis), Belpatra (Aegle } \\
\text { marmelas), kachoor (Curcuma vasica), Badjata (Ficus begalensis), kikarfa (Acacia } \\
\text { Arabica), Kuchla sudha ( strychnos nuxvomica), Kaali Jeeri (Centratherum anthel- } \\
\text { minticum), Kutki (Picrorhiza kurroa), Jumunguthli (Syzygium cumini), Chirayata } \\
\text { (Swertica chirata), Haldi (Curcuma longa), Methi (Trigonella foenum graecum), } \\
\text { Saptrangi (Salacia chinensis). }\end{array}$ \\
\hline 2 & $\begin{array}{c}\text { Dabur Madhu Rakshak } \\
\text { Activ }\end{array}$ & Dabur & $\begin{array}{l}\text { offiicinali (Ginger), Vijaysar (Petrocarpus marsupium), Tejpatra (Cinnamomum } \\
\text { tamala), Jamun seed (Eugenia jumbolna), Guldmar (Gymnena sylvestre), Kali } \\
\text { Miricha (Piper nigrum), Neem leaves (Azadiracheta indica), Methi (Trigonella foe- } \\
\text { num-graeium), Shuddha shilajit, Bhavana Dravyas, Karela fruit (Momordica Charan- } \\
\text { tia), Amla (Phyllanthus emblica), Hareetaki (Terminalia chebula), Bahera (Termina- } \\
\text { lia belerica), Preservatives sodium methyl paraben,Sodium propyl paraben. }\end{array}$ \\
\hline 3 & BGR-34 OR IME-9 & CSIR & $\begin{array}{l}\text { Daraharidra (Berberi saristata), Vijayasar (Pterocarpus Marsupium), Gudmar } \\
\text { (Gymnema stlvestre) Majeeth (Rubia Cordifolia), Methika (Trigonella foenum grae- } \\
\text { cum), Giloy (Tinaspura cordifolia), Shilajeet sudh (RTS-1) (Purified Black Bitimen ) }\end{array}$ \\
\hline 4 & Syndrex & Plethico Laboretaries & Germinated Fenugreek seed extract \\
\hline 5 & Gurmar Power & $\begin{array}{l}\text { Garry and sun natural } \\
\text { Remedies }\end{array}$ & Gurmar (Gymnema sylvestre ) \\
\hline 6 & Diabetes Daily Care & Nature's Health Supply & $\begin{array}{l}\text { Alpha Lipoic Acid, Cinnamon 4\% Extract, Chromax, Vanadium, Fenugree 50\% } \\
\text { extract ,gymnema sylvestre 25\% extract Monordica 7\% extrac Licorice Root 20\% } \\
\text { extract. }\end{array}$ \\
\hline 7 & Dia-Care & $\begin{array}{l}\text { Admark Herbals } \\
\text { Limited }\end{array}$ & Sanjeevan Mool, Himej ,Jambu beej, Kadu, Namejav, Neem chal. \\
\hline 8 & Pancreatic tonic $180 \mathrm{cp}$ & $\begin{array}{l}\text { ayurvedic herbal sup- } \\
\text { plement }\end{array}$ & $\begin{array}{l}\text { Pterocarpus marsupium, Gymnema sylvestre, Momordica charantia, syzygium cumini, } \\
\text { Trigonella foenum graceum, Azadirachta, ficus, racemosa, Aegle marmelos, Cinnamo- } \\
\text { mum tamala, }\end{array}$ \\
\hline 9 & $\begin{array}{l}\text { Ayurveda alternative } \\
\text { herbal forumla to } \\
\text { Diabetes }\end{array}$ & Chakrapani Ayurveda & $\begin{array}{l}\text { Gurmar (Gymnema sylvestre) Karela (Momordica charantia) Pushkarmoo (Inula } \\
\text { racemosa) Jamun Gulti (Syzygium cumini) Neem (Azadirachta indiac) methika } \\
\text { (Trigonella foemum gracecum) Guduchi (Tinospora cordifalia) }\end{array}$ \\
\hline 10 & Diasulin & $\begin{array}{l}\text { Dansih medicine Chem- } \\
\text { ical company }\end{array}$ & $\begin{array}{l}\text { Cassia auriculata, Coccinia indiac, Curcuma longa, Emblica officinalis, Gymnema syl- } \\
\text { vestre, Momordica charantia, Scoparia dulcis, Syzygium cumini, Tinospora cordifolia, } \\
\text { Trigonella foenum graecum }\end{array}$ \\
\hline 11 & Doabecon & Himalaya & $\begin{array}{c}\text { Gymnema sylvestre, Pterocarpus marsupium, Glycyrrhiza glabra, Casearia esculenta } \\
\text {, Syzygium cumini, Asparagus racemossus, Boerhavia diffusa, Sphaeranthus indicate, } \\
\text { Tinospora cordifolia, swertia chirata, Tribulu terrestris, Phyllanthus amarus, Gmelina } \\
\text { arborea, Gossypium herbaceum, Berberis aristata, Aloe vera, Triphala, Commiphora } \\
\text { Wighlii, Shilajeet, Momordica Charantia, Piper nigrum, Ocimum sanctum, Abutilon } \\
\text { indicum, Curcuma longa, Rumex maritimus }\end{array}$ \\
\hline 12 & Bitter gourd Power & $\begin{array}{l}\text { Garry and Sun natural } \\
\text { Remedies }\end{array}$ & Bitter gourd (Momordica charantia) \\
\hline 13 & Epinsulin & Swastik Formulations & Vijaysar (Pterocarpus marsupium) \\
\hline 14 & Dibecure & Nature beaute santé & Juglans regia, Berberis vulgaris, Erytherea, millefolium, Taraxacum \\
\hline 15 & Diabeta & $\begin{array}{l}\text { Ayurvedic cure Ayurve- } \\
\text { dic Herbal Health } \\
\text { Products }\end{array}$ & $\begin{array}{c}\text { Gymnema sylvestre, Vinca rosea (Periwinkle). Curcuma longa (Turmeric), Azadirach- } \\
\text { ta indica (Neem), Pterocarpus marsupium (Kino Tree), Momordica charantia (Bitter } \\
\text { Gourd), Syzygiumcumini (black Plum) Acacia Arabica (black Babhul), Tinospora } \\
\text { cordifolia, Zingiber }\end{array}$ \\
\hline
\end{tabular}


Beside these herbal plant and spices there are several numbers of herbal medicines that have antidiabetic and anti- cancer property but none of these herbal plants could be developed as a drug for diabetes and cancer. The above mentioned all the herbal plant and plant products are key to excellent health and longevity, which all have a high proportion of micronutrients compared to macronutrients. The macronutrients are those nutrients that don't contain calories and have vitamins, minerals and phytochemicals. The phytochemicals have property to deal with chronic disease like diabetes, cancer, heart attack etc.

The nutritional science can be representing the heath equation: -

Nutrient

$\mathrm{N}$

$$
\text { Health }=\text { or } H=
$$

Calories

(Joel Fuhrman; www.allergykids.com $>$ Home $>$ what you can) [177] sometime herbal medicine system have misinterpreted as being unscientific and anachronistic, there long-term existence proves that they are able to compete with western drug. Thus, the single anti- diabetic herbal plant extract has been thousands of phytochemicals may have multiple benefits by targeting several metabolic pathways and essentially "Killing several birds with one stone".

Herbal care of traditional system of medicine are used throughout the world and from centuries herbs have been the original source for most of the drugs .Medicinal plants contain so many chemical compounds which are the major source of therapeutic agents to cure human disease from different recent discoveries and advancement in medicinal and aromatic plants have led to the health care of human. Herbal remedies have been used by people in different parts of the world treat various disease like cancer and diabetes. When it comes to diabetes and cancer, people have strange belief in alternative therapy. Considering the astounding findings being thrown up by studies on the medicinal properties of herbs, usefulness of herbal drugs in diabetes and cancer.

The two most important aim herbal therapy is:

a. To maintain the health of healthy people.

b. To cure the disease of sick people.

The aim of herbal therapy is making a happy, healthy, and peaceful society. Ayurveda is science dealing not only with treatment of some disease but is a complete way of life. Ayurvedic treatment could be a successful alternative to allopathic treatment. It may be taken in conjunction with allopathic treatment for reducing the dose of allopathic drugs, reducing side effects of allopathic drugs, and making early wellbeing of patient and adding quality of life [178]. From the different investigation it appeared that natural plant products might have some ingredients to increase the output of insulin by binding to receptors of the Betacells of the islets of Langerhan's located in the pancreas. Once they bind to sulphonylurea's receptors, the K+-ATP channels are probably closed and therefore the membrane is depolarized and insulin production is stimulated $[179,180]$.

\section{Herbal Drugs Formation}

Many Indian herbal formations easily available in market \& regularly taken by diabetic patent on the advice of Physicians or diabetologist.

Divya madhunasini vatic manufactured by 'Patanjali' is a herbal remedy and it has no side effects. It has been observed that madhunasani reduces the tendency of eating sweet and l-inhance the power of glucose absorption during diagestion. It promotes normal blood sugar levels. This vati increase levels of glycogen in the liver by optimizing. The serum lipids \& helps to increase the levels of HDL and lower the level of LDL. This vati repair \& regenerate the beta cells of Pancrease and prevent Them from oxidative stress. It also Incerease C-peptide levels in body.

Madhu Rakshak Active manufactured by Dabur claimed to effective for anti-diabetic, antioxidant \& immunomodulator. That provide comprehensive protection from diabetes \& its complication. It regenerates functional pancreatic beta cells. Dabur Madhu rakshak should be taken one two teaspoonsful (3-6 g) morning \& evening with water before meals or directed by physician. Safety of few ingredients in madhu rakshak is not demonstrated in pregnancy furthermore diabetics taking other hypoglycemic drugs or insulin should use dabur madhu rakshak with caution.

IME-9 developed by CCRAS (Ministry of Ayush Govt. Of India). IME-9 is very beneficial if taken with moringa plus capsules (Synergistic medicine to control diabetes) Normally IME-9 should be taken for3 months with one capsule twice a day. It should be taken half before meal. IME-9 \& Moringa Tablets help regenerating beta cells, reduce insulin resistance insulin production.

Syndrex manufactured by plethico Laboratory contains extract of germinated Trigonella foenum graecum (Fenugreak) seed. That lower blood glucose \& repairs the beta cells of body. Gurmar powder manufactured by garry and sun is an antidiabeticdrug which suppress the intestinal absorption of di-sucihrides. Which prevents increase blood sugar levels. Gurmar stimulates insulin secretion \& has blood glucose reducing property.

Diabeties Daily Care manufactured by Nature's Health supply is a Unique, Natural formula which effectively Improves sugar metabolism. Diabetis daily careTM was formulated for NIDDM. Dia-care manufactured by Admark herbals Ltd. Is claimed to be effective for both Type1, Type-2 diabetis within 90 days of treatment \& cures within 18 months. The test of the drug is very 


\section{Current Research in Diabetes \& Obesity Journal}

better. It is a pure herbal formulation without any side effects [181-185].

a. Pancreatic Tonic (Ayurvedic supplement): Pancreas tonic is mixture of traditional Ayurvedic herbs currently available as food supplement.

b. Diabeta a formulation of Ayurvedic cure marketed in Capsule from an antidiabeto-genic with immune modulator, antistress, anti - hyperlipidemic, heptoprotective of plant origin.

c. Diabecon manufactured by Himalaya is reported to increase utilization of glucose, promote B-cell resturtion \& increase C-peptide level. It also prefect Beta cells from oxidative stress.

d. Episulin manufactured by swastika formulation. It I play role in the conversion proinsulin to insulin by increasing cathepsin activity. It is curative for both type- 1 \& Type- 2 diabetes.

\section{Conclusion}

In the summary finally, we conclude that the prevention is better than treatment. The use of allopathic medicines in diabetes such as insulin and insulin analog, metformin, sulphonylurea, TZDs etc. have several side effects and causes most dangerous type of disease including cancer. Natural products specially formed by plant have found to be beneficial in treatment of disease such as diabetes and cancer. The plant-based products such as vegetables, fruits, grains, and spices have significant number of phytochemicals that may provide health benefits beyond basic nutrition reduce risk of several chronic diseases the most champion fact about herbal medicines have no side effects. So, eat for health be healthy always.

\section{References}

1. Zendehdal K, Nyren O, Ostenson CG, Adami HO, Ekbom A, et al. (2003) Cancer incidence in patients with type I diabetes mellitus : a population-based cohort study in Sweden. J Natl Cancer Int 95: 17971800.

2. Coaghlin SS, Cale EE, Teras LR, Petrelli J, Thun J (2004) Diabetes mellitus as a predictor of cancer mortality in a large cohort of US adults, Am J Epidemiol 159(12): 1160-1167.

3. Larsson SC, Orsini N, Wolk A (2005) Diabetes mellitus and risk of colorectal cancer: a melta analysis. J Natl Cancer Inst 97: 1679-1687.

4. R Huxley, A Ansary Moghaddam, A Berrington de González, F Barzi (2005) Type-2 diabetes and pancreas cancer: a meta-analysis of 36 studies. Br J cancer 92: 20762083.

5. Larsson SC, Mantgoros CS, Wolk A (2007) Diabetes mellitus and risk of breast cancer: a meta-analysis. Int J Cancer 121: 856-862.

6. Giovannucci E, Michaud D (2007) The role of obesity and related metabolic disturbances in cancers of the colon, prostate and pancreas. Gastroenterology 132: 2208-2225.

7. Johnson JA, Carstensen B, Witte D, Bowker SL, Lipscombe L, et al. (2012) Diabetes and cancer (1): evaluating the temporal relationship between type-2 diabetes and cancer incidence. Diabetologia 55: 16072618.
8. Johnson JA, Bowker SL, Richardson K, Marra CA, (2011) Time-varying incidence of cancer after the onset of type-2 diabetes: evidence of potential detection bias. Diabetologia 54: 22632271.

9. Pollak M (2009) Do cancer cells care if their host \& hungry. Cell Metab 9: 401-403.

10.Zakikhani M, Dowling R, Fantus IG, Sonsenbery N, Pollak M (2006) Metformin is an AMP- Kinase dependor growth inhibitor for brest cancer cells. Cancer Res 66: 10269-10273.

11. Dowling RJ, Zakikhani M, Fantus IG, Pollak M, Sosenberg N (2007) Metformin inhibits mammalian target of rapamycin- dependent translation initiation in brest cancer cells. Cancer Res 67: 1080410812.

12. Burton JD, Goldenberg DM, Blumenthal RD (2008) Potential of peroxisome proliferator activated receptor gamma antagonist compounds as therapeutic agents for a wide range of cancer types. PPAR Res 2008: 494161.

13. Tachibana K, Yamasaki D, Ishimoto K, Dol T (2008) The role of PPARs in cancer. PPAR Res 2008: 102737.

14. Gerstein HC (2010) Does insulin therapy promote, reduce, or have a neutral effect on cancer. JAMA 303: 446-447.

15. El Serag HB, Hampol H, Javadi F (2006) The association between diabetes and hepatocelluar carcinoma: A systematic review of epidemiological evidence. Clin Gastroenterol Hepatol 4: 369-380.

16. Huxley R, Ansary Maghaddam A, Berrington de Gonzale A, Barzi F, Woodward M (2005) Type-2 diabetes and pancreatic cancer: A metaanalysis of 36 studies. Br J Cancer 92: 20762083.

17. Friberg E, Orsini N, Mantzoroz CS, Wolk A (2007) Diabetes mellitus and risk of endometrial cancer. A meta-analysis. Diabetelogia 50: 13651374.

18. Larsson SC, Mantzoros CS, Wolk S (2007) Diabetes mellitus and risk of brest cancer: a metaanalysis. Int J Cancer 121: 856-862.

19. Larsson SC, Orsini N, Wolk A (2005) Diabetes mellitus and risk of colorectal cancer: a metaanalysis. J Natl Cancer Inst 97: 1679-1686.

20. Larsson SC, Orsini N, Brismar K, Wolk A (2006) Diabetes mellitus and risk of bladder cancer: a meta-analysis. Diabetologia 49: 2819-2823.

21. Mitri J, Castillo J, Pittas, A.G (2005) Diabetes and risk of non-Hodgkin's lymphoma: a meta-analysis of observational studies. Diabetes Care 31: 2391-2397.

22. Larsson SC, Wolk A, Cohort Studies (2011) Diabetes mellitus and incident of kidney cancer: a meta-analysis of cohort studies. Diabetologia 54: 1013-1018.

23. Giovannucci E, Harlan DM, Archer MC (2010) Diabetes and cancer: a consensus report. Diabetes Care 33: 1674-1685.

24. Kasper JS, Giovannucci E (2006) A meta-analysis of diabetes mellitus and the risk of prostate cancer. Cancer Epidemiol Bio markers Prev 15: 2056-2062.

25. Hall GC, Robert CM, Boulis M, Mo J, Mac-Rac KD (2005) Diabetes and the risk of lung cancer. Diabetes Care 28: 590-594.

26. Weiderpass E, Ye W, Vainio H, Kaaks R, Adami HO (2002) Diabetes mellitus and ovarian cancer (Sweden). Cancer Causes Control 13: 759764.

27. Yamagata H, Kigohara Y, Nakamura S (2005) Impact of fasting plasma glucose levels on gastric cancer incidence in a Japanese population: the Hisayama study. Diabetes Care 28: 789794. 


\section{Current Research in Diabetes \& Obesity Journal}

28. World cancer Report (2008) Boyle P, Bernard L, (Edt.), Cedex, France world Health organization, International Agency for Research on cancer.

29. IDF diabetes Atlas (2009) [article online] (4 $4^{\text {th }}$ edn.), Brussels, Belgium, International Diabetes.

30. Lieu R, Ean Z, Edgerton SM, Deng XS, Alimoa JN, et al. (2009) Metformin induced unique biological and molecular resonances in triple negative breast cancer cells. Cell Cycle 8: 2031-2040.

31. Lopez AD, Mathers CD, Ezzati M, Jamison DT, Murray C (2006) Global and regional burden of disease and risk Factors 2001: systematic analysis of population health data. Lancet 367: 5747-1757.

32. Giovnnucci E, Harlan DM, Archer MC (2010) Diabetes and cancer: A Consensus report. A cancer journal for clinicians 60(4): 207-221.

33. Centers for Disease contra and Prevention (CDC) Prevalence of overweight and obesity by among adults with diagnosed diabetes - United States, 1988 -1994 and 1999 - 2002. 173. Morbidity and Mortality (2004) weekly Report 53(45): 1066-1068.

34. Vecchai C, La, Giordonao SH, Hortobagyi GN, Chabner B (2011) Overweight, obesity and risk of breast cancer: interlocking pieces of the puzzle. Oncologist 16(6): 726-729.

35. Leroith D, Novosyadly R, Gallagher JE (2008) Obesity and type2diabetes are associated with an increased risk of developing cancer and worse prognosis; epidemiological and mechanistic evidence. Exp Clin Endocrinol Diabetes 116(1): 54-56.

36. Eliassen AH, Colditz GA, Rosner B, Willett W, Honkinson SE (2006) Adult weight change and risk of postmenopausal breast cancer. JAMA 296(2): 193-201.

37. Pollak M (2008) Insulin and insulin like growth factor singnalling in neoplasia. Nature Reviews Cancer 8(12): 915-928.

38. Krishnan S, Rosenberg L, Singer M (2007) Glycemic index, glycemic load, and cereal fiber intake and risk of type 2 diabetes in VS black women. Archives of Internal Medicine 167(21): 2304-2309.

39. Barbclay AW, Petocz P, McMillan-Prince J (2008) Glycomic index, glycemic load and chronic disease risk-a meta analysis of observational studies. Am J Clin Nutr 87(3): 627-637.

40. Dong JY, Quin LQ (2011) Dietary glycemic index, glycemic, load, and risk of breast cancer: meta analysis of prospective cohiort studies. Breast cancer Reserch and Treatment 126(2): 287-294.

41. Hu J, Vacchia La C, Augsutin LS (2013) Glycemic index, glycemic load and cancer risk. Annals of Oncology 24(1): 245-251.

42. Johnson JA, Pollak M (2010) Insulin, glucose and increased risk of cancer in patients with type-2 diabetes. Diabetologia 53: 2086-2088.

43. Smith V, Gale EAM (2009) Does diabetes therapy influence the risk of cancer. Diabetologia 52: 1699-1708.

44. Evans JMM, Donenelly LA, Emsile Smith AM, Alessi DR, Morris AD (2005) Metformin and reduced risk of cancer in diabetic patients. BMJ 330: 1304-1305.

45. Currie CJ, Poole CD, Gale EAM (2009) The influence of glucoselowering therapies on cancer risk in type- 2 diabetes. Diabetologia 52 1766-1777.

46. Libby G, Donnelly LA, Donnan PT, Alessi DR, Morris AD, et al. (2009) New users of metformin are at low risk of incident cancer: a cohort study among people with type2 diabetes. Diabetes Care 32: 16201625.

47. Yang YX, Hennessy S, Lewis JD (2004) Insulin therapy and colorectal cancer risk among type-2 diabetes mellitus patients. Gastroenterology 127: $1044-1050$.
48. Bowker SL, Majumdar SR, Veugelers P, Johnson JA (2006) Increased cancer-related mortality for patients with type-2 diabetes who use sulphonylureas or insulin. Diabetes Care 29: 254-258.

49. Hemkens LG, Grouven U, Bender R (2009) Risk of malignancies in patients with diabetes treated with human insulin or insulin analogues: a cohort study. Diabetologia 52: 1732-1744.

50. Mannucci E, Monami M, Balzi D (2010) Doses of insulin and its analogues and cancer occurrence in insulin treated type-2 diabetic patients. Diabetes Care 33: 1997-2003.

51. Govindarajan R, Ratnasmghe L, Simmons DL (2007) Thiazolidinediones and risk of lung, prostate and colon cancer in patients with diabetes. J Clin Oncol 25: 1476-1481.

52. Lewis JD, Ferrara A, Peng T (2011) Risk of bladder cancer among diabetic patients treated with pioglitazone: interim report of a longitudinal cohort study. Diabetes Care 34: 916-922.

53. Jonasson JM, Ljong R, Tlback M, Haglund B, Gudb Jornsdottir S, et al (2009) Insulin glargine use and short term incidence of malignancies a Population based follow -up study in Sweden. Diabetologia 52:17451754

54. Colhoun HM, SDRN Epidemiology Group (2009) Use of insulin glargine and cancer incidence in Scotland- a study from Scottish Diabetes Research Network Epidemology Group. Diabetologia, 52: 1755-1765.

55. Elashoff M, Matveyenko AV, Gier B, Elashoff R, Butler PC (2011) Pancreatitis, Pancreatic, and thyroid cancer along with glucogon - like peptide -1based therapies. Gastroenterology 141: 150-156.

56. Algire C, Amrein L, Zakikhani M, Panasei L, Pollak M (2010) Metformin block the stimulative effect of a high-energy diet on colon carcinoma growth in vivo and is associated with reduced expression of fatty acid synthase. Endocr Relate Cancer 7: 351-360.

57.Zakikhani M, Dowling R, Entus JG, Sosenberg N, Pollak M (2006) Metformin is an AMP Kinase-dependant growth inhibitor for breast cancer cells. Cancer Res 66: 10269-10273.

58. Jee SH, Ohrr H, Sull JW, Yun JE, Ji M, Samet JM (2005) Fasting serum glucose level and cancer risk in Korean men and women. J AMA 293: 194-202.

59. Stocks T, Rapp K, Bjorge T (2009) Blood glucose and risk of incidence and fatal cancer in metabolic syndrome and cancer project (Me- Can) analysis of six prospective cohorts. Ploos Med 6: e100201.

60. Pollak M (2008) Insulin and insulin like growth factor signaling in neoplasia. Nat Rev Cancer 8: 915-928

61. Jabboun S (2008) Primary care physicians and Insulin initiation: multiple barriers lack of knowledge or both. Int J Clin Pract 62: 845847.

62. Schoen RE, Tangen CM, Kuller LH (1999) Increased blood glucose and insulin, body size and incident colorectal cancer. J Natl Cancer Inst 91: 1147-1154.

63. Tannock IF, Kopelyan I (1986) influence of glucose concentration on growth and formation of necrosis in spheroid derived from a human bladder cancer cell line. Cancer Res 46: 31053110.

64. Kaaks R, Toniolo P, Akhmedkhanov A (2000) Serum c-peptide insulin like growth factor (IGF) -1, IGF - binding proteins, and colorectal cancer risk in women. J Natl Cancer Inst 92: 159-1600.

65. Ma J, Giovanucci E, Pollak M (2004) A Prospective study of plasma C-peptide and colorectal cancer risk in men. J Natl Cancer Inst 96: 546553.

66. Hsu IR, Kim SP, Kabir M, Bergman RN (2007) Metabolic Syndrome, hyperinsulinemia and cancer. Am J Clinical Nutr 86: 8675-8715. 


\section{Current Research in Diabetes \& Obesity Journal}

67. Holly JMP, Perks CM (2008) Cancer as an endocrine problem. Best Pract Res Clin Endocrinal Metformin 22: 539-550.

68. Pollak M, Rossell Jones D (2010) Insulin analogues and cancer risk: cause for concern or cause for celebre. Int J Clin Pract 64: 628-636.

69. Shukla A, Grisouard J, Ehemann V, Hermani A, Enzmann H, Mayer D (2009) Analysis of signaling pathways related to cell proliferation stimulated by insulin analogs in human memory epithelial cell lines. Endor Relat Cancer 16: 429-441.

70. Kurtzhals R, Schaffer J, Sarensen A, Kristensen C, Jonassen C, Schmids C, Trjih T (2000) Correlations of receptor bindings and mitogenic potencies of insulin analogs designed for clinical use. Diabetes 49: 999-1005.

71. Liefyendahl E, Arnavist HJ (2008) Mitogenic effect of the insulin analogue glargine in malignant cells in comparison with insulin and IGF-1. Horm Metab Res 40: 369-394.

72. Jaw JH, Habibi G, Hu K, Masoudi H, Wang MY, et al. (2008) Phosphorylated insulin like growth factor 1 /insulin receptor is present in all breast cancer subtypes and is related to poor survival. Cancer Res 68: 10238-10246.

73. Coy ME, Glaeve ME, Zakikhani M, Bell BH (2009) Insulin receptor expression by human prostate cancers. Prostate 69: 33-40.

74. Berger M (2000) Safely of insulin glargine. Lancet 356: 2013.

75. Ebeling P, Tuominen JA, Koivisto VA (1996) Insulin analogues and carcinoma of the breast, Diabetologia 39(1): 124-125.

76. Hansen BF, Danielsen GM, Drejer K (1996) Sustained signaling from the insulin receptor after stimulation with insulin analogoues exhibiting increased mitogenic potency. Biochem J 315 (Pt 1): 271-279.

77. Slieker LJ, Brooke GS, Dimarchi RD, D B Flora, L K Green et al, (1997) Modifications in the B10 and B26-30 regions of the B-chain of human insulin after affinity for the human IGF-1 receptor more than for the insulin receptor. Diabetologia 40(S2): S54-S61.

78. Jorgensen L, Dideriksen L, Drejer K (1992) Carcinogenic effect of the human insulin analogue B10 Asp in female rats, Diabetologia 35 (Suppl1): A3.

79. Kurtzhals P, Schaffer L, Sorensen A, Kristensen C, Jonassen I (2000) correlations of receptor binding and metabolic and mitogenic potencies of insulin analogs designed for clinical use, Diabetes 49(6): 999-1005.

80. Erbel S, Biichler MW, Reers C (2008) Proliferation of colo-357 pancreatic carcinoma cells and survival of patients with pancreatic carcinoma are not altered by insulin glargine. Diabetes Care 31(6): 1105-1111.

81. Weinstein D, Simon M, Yehezkel E, Laron Z, Werner H (2009) Insulin analog display IGF-1 like mitogenic and anti-apoptotic activities in caltured cancer cells. Diabetes Metab Res Rev 25(1): 41-49.

82. Kuerzel GU, Shukla U, Scholtz HE (2003) Biotransformation of insulin glargine after subcutaneous injection in healthy subjects. Curr Med Res Opi 19(1): 34-40.

83. Agin A, Jeandidier N, Gasser F, Racker D, Sapin R (2007) Glargine blood biotransformation invitro appraisal with human insulin immunoassay. Diabetes Metab 33(3): 205-212.

84. Rosenstock J, Eonseca V, McGill JR, Riddle M, Halle JP, et al. (2009) Similar risk of malignancy with insulin glargine and neutral protamine Hegedorn (NPH) insulin in patients with type-2 diabetes findings from a 5-year randomized open-level study. Diabetologia 52: 1971-1973.

85. Verdonck Sangeter B, Van Heijst AN, De Groot G, Macs RA (1981) Buformin concentrations in a case of fatal lactic acidosis. Diabetologia 20(1): 45-46.
86. Eurich McAlister FA, Blackburn DF, Blackburn DF, Majumdar SR, Tsuyuki RT, et al. (2007) Benefits and harms of antidiabetic agents in patients with diabetes and heart failure: systematic review. BMJ 335(7618): 497.

87. Fimognari Pastorelli R, Incalzi RA (2006) Phenforin induced lactic acidosis in an older diabetic patient: a recurrent drama (Phenformin and lactic acidosis). Diabetes care 29(4): 950-951.

88. Nathan DM, Buse JB, Davidson MB, Ferrannini E, Holman RR (2009) American diabetes association, European Association for study of Diabetes Medical management of hyperglycemia in type-2 diabetes: a consensus algorithm for the initiation and adjustment of therapy a consensus statement of the American Diabetes Association and the European Association for the study of Diabetes. Diabetes Care 32: 193203.

89. Shaw RL, Lamia KA, Vasaurg D, Koo SH, Bardeesv N, et al. (2005) The kinase LKR1 mediates glucose homeostasis in liver and therapeutic effects of metformin. 310: 1642-1646.

90. Alimova JN, Liu R, Ean Z, Edgerton SM, Dillon T, et al. (2009) Metformin inhibits breast cancer cell growth colony formation and induces cell cycle arrest in vitro. cell cycle 8: 909-915.

91. Algire C, Zakikhani M, Blouin ML, Shuai JH, Pollak M (2008) Metformin attenuates the stimulatory effect of a high-energy diet on in vivo carcinoma growth. Endocr Relat Cancer 15(3): 833-839.

92. Schimmack G, Defronzo RA, Musi N (2006) AMP-activated protein kinase: role in metabolism and therapeutic implications. Diabetes Obes Metab 8(6): 591-602.

93. Sahra IB, Laurent K, Loubat A (2008) The antidiabetic drug metformin exerts an antitumor effect in vitro and in vivo through a decrease in cyclin D1 level. Oncogene 27: 3576-3586.

94. Dowling RL, Zakikhani M, Eantus JG, Pollak M, Sosenberg N (2007) Metformin inhibits mammalian target of rapamycin-dependent translation intiation in breast cancer cells. Cancer 67(22): 1080410812.

95. Vazauez- Martin A, Oliveras Eerraros C, Memendez JA (2009) The antidiabetic drug metformin suppresses the HER? (erbR-2) oncoprotein overpression via-inhibition of the mTOR effectors P70S6K1 in human breast carcinoma cells. Cell Cycle 8(1): 88-96.

96. Hirsch HA, Ilionoulos D, Tsichlis PN, Struhl K (2009) Metformin selectively targets cancer stem cells and acts together with chemotherapy to block tumor growth and prolong remission. Cancer Res 69(19): 757-7511.

97. Oliveras-Eerraros C, Vezaued-Martin A, Menendez J (2009) Genomewide inhibitory impact of the AMPK activator metformin on [Kinesins tubulins histones ouroras and polo-like kinases] M-Phase cell cycle genes in human breast cancer cells, Cell Cycle 8(10) :1633-1636.

98. Anisimov VN, Rerstein LM, Egormin RA, Riskunova TS, Ponovich JG, et al. (2005) Effect of metformin on life span and on the development of spontaneous mammary tumors in HER3/new transgenic mice. Exp Gerontal 40(8-9): 685-693.

99. Prospective Diabetes Group UK (1998) Effect of intensive blood glucose control with metformin on complications in overweight patients with type-2 diabetes UK PDS34. Lancet 352(9131): 855-865.

100. Evans JM, Donnelly JA, Emslie Smith AM, Alessi DR, Morris AD (2005) Metformin and reduce risk of cancer in diabetic patients. BM] 330(7503): 1304-1305.

101. Hemkens LG, Grouven IL, Render R, Giinster C, Gutschmidt S, et al (2009) Risk of malignancies in patients with diabetes treated with human insulin or insulin analogues: a cohort study. Diabetologia 52(9): 521732-1744. 


\section{Current Research in Diabetes \& Obesity Journal}

102. Decenst A, Puntoni M, Goodwin P (2010) Metformin and cancer risk in diabetic patients: a systematic review and meta-analysis, Cancer Prev Res 39(11): 1451-1461.

103. Genevra Pittman (2012) (Reuters Health)- A new study links the diabetes drug metformin to fewer cases of pancreatic cancer at least in women-but finds other diabetes medications are associated with a higher risk of the disease Diabetes drug tied to pancreatic cancer risk, New York, USA.

104. Bowker SL, Majumdar SR, Veugulers P, Johnson JI (2006) Increased cancer related mortality for nutrients with type-2 diabetes who use sulphonylureas or insulin. Diabetes Care 29(2): 254-258.

105. Monami M, Lamanna C, Ralzi D, Marchionni N, Mannucci N,et. al, (2009) Sulphonylureas and cancer a case-control study. Acta Diabetol 46(4): 279-284

106. Wright IJ, Stanford JI (2009) Metformin use and prostate cancer in caucasian men results from a population based case control study. Cancer Causes Control 20(9): 1617-1622.

107. Landman GW, Kleefstra N, Van Hateren KL, Groenier KH, Gans RO, et al. (2010) Metformin associated with lower cancer mortality in type2 diabetes: ZODIAC- 16. Diabetes Care 33(2): 322-326.

108. http://news.yahoo.com/metforminoutperforms-outpsrformscommon-class-diabetes-drugsstudy-1604.

109. Samantha LB, Sumit BM, Paul V, Jeffery J (2006) Increased cancerrelated mortality for patients with Type-2 diabetes who use sulphonylureas or insulin. Diabetes Care 29(2): 254-258.

110. Bodmer M, Becker C, Meier, Jick SS, Meir RC (2012) Use of antidiabetic agents and the risk of Pancreatic cancer: A case control analysis, Am J Gastroenterol advance online publication 107(4): 620-626.

111. Saydah SH, Loria CM, Eberhardt MS, Brancati FL (2003) Abnorma glucose tolerance and the risk of cancer death in the United States. Am J Epidemiol 157(12): 1092-1100.

112. Levine W, Dyer AR, Shekelle RB, Schoenberger JA, Atamler J (1990) Post-load plasma glucose and cancer mortality in middle ages men and women:12 year follow-up findings of the Chicago Heart Association Detection Project in Industry. Am J Epidemiol 131(2): 254-262.

113. Michels KB, Solomon CG, Hu FB, Rosner BA, Hanknson SE, et al. (2003) Type-2 diabetes and subsequent incidence of breast cancer in the Nurses Health Study. Diabetes Care 26(6): 1752-1758.

114. Weiderpass E, Gridley, G Nyren O, Ekbom A, Persson I, et al. (1997) Diabetes mellitus and risk of large bowel cancer, J Natl Cancer Inst 89(9): 660-661.

115. Maatela J, Aromaa A, Salmi T, Pohja M, Vuento M, et al, (1994) The risk of endometrial cancer in diabetic and hypertensive patients: a nationwide record- linkage study in Finland, Ann chir Gynaecol Suppl 208: 20-24.

116. La Vecchora C, Negri E, Franceschi S, D Avango B, Boyle P (1994) A case-control study of diabetes mellitus and cancer risk. Br J Cancer 70(5): 950-953.

117. Everchart J, Wright D (1995) Diabetes mellitus as a risk factor for pancreatic cancer: a meta-analysis. J AMA 273(20): 1605-1609.

118. Adami HO, Mclaughlin J, Ekbom A, Berne C, Silverman D, et al. (1991) Cancer risk in Patients with diabetes mellitus, Cancer Causes Control 2: 307-314.

119. Balkau B, Barrett - Connor E, E Schwege E, Richard JL, Claude JR, et al, (1993) Diabetes and Pancreatic carcinoma. Diabetes metab 19(5): 458-462.
120. Silverman DT, Schiffman M, Everchart I, Glodstein A, Lillemoe KD, et al. (1999) Diabetes mellitus, other medical conditions and familial history of cancer risk factors for pancreatic cancer. $\mathrm{BrJ}$ Cancer 80(11): 1830-1837.

121. Hjalgrim H, Frisch M, Ekbom A, Kgvi KO, Melbye M, et al. (1997) Cancer and diabetes - a follow up study of two- Population - based cohorts of diabetic patients, J Intern Med 241(6): 471-475.

122. Hu FB, Manson JE, Liu S, Hunter D, Colditz GA, et al. (1999) Prospective study of adult onset diabetes mellitus (type2)and risk of colorectal cancer in women. J Natl Cancer Inst 91(6): 542 -547.

123. Will IC, Galuska DA, Vinicor F, Calle EE (1998) Colorectal cancer: another complication of diabetes mellitus? Am J Epidemiol 147(9): 8166-8825.

124. Ashcroft FM, Gribble FM (1999) ATP-sensitive K+ channels and insulin secretion: their role in health and disease, Diabetologia 42(8): 903-919.

125. Nichols CG (2006) K+-ATP channels as molecular sensors of cellular metabolism. Nature 440(7083): 470-476.

126. Thomas PM, Cote GJ, Hallman DM, Mathew PM (1995) Homozygosity mapping to chromosome 11p, of the gene for familial persistant hyperinsulinemic hypoglycemia of infancy, Am J Hum Genet 56(2): 416- 421.

127. Nestorowicz A, Wilson BA, Schoor KP, Inoue H, Glaser B, et al. (1996) Mutation in sulphonylurea receptor gene are associated with familial hyperinsulinism In Ashkenazi Jews. Hum Mol Genet 5(11): 18131822.

128. Thomas P, Ye Y, Lightner E (1996) Mutation of the pancreatic islet inward rectifier, Kir 6.2 also leads to familial persistent hyperinsulinemic hypoglycemia of infancy, Hum Mol Genet 5(11) 1809-1812

129. Nichols CG, Shyng SL, Nestorowicz A, Glaser B, Clamet JP (1996) Adenosine diphosphate as an intracellular regulator of insulin secretion. Science 272(2569): 1785-1787.

130. Nestorowicz A, Inagaki N, Gonoi T, Schoor KP, Wilsion BA (1997) A nonsense mutation in the inward rectifier potassium channel gene , Kir 6.2, is associated with familial hyperinsulinism. Diabetes 46(11): 1743-1748

131. Aynsley Green A, Polak JM, Bloom SR, Gough MH, Keeling J (1981) Nesidioblestosis of the pancreas : definition of the syndrome and the management of the severe neonatal hyperinsulinemic hypoglycemia. Arch Dis Child 56(7): 496-508.

132. Huopio H, Shyng SL, Otonkoski T, Nichols CG (2002) K (ATP) Channels and insulin secretion disorders. Am J Physiol Endocrinal Metab 283(2): E 207-216.

133. Miki T, Nagashima K, Tashiro G, Kotake K, Yoshitomi H (1998) Defective insulin secretion and inhanced insulin action in K+-ATP channel - deficient mice. Proc Natl Acad Sci USA IS 95(18):1040210406.

134. Shiota C Larsson O, Shelton KD, Shiota M, Efanov AM (2002) Sulphonylurea receptor type 1 Knock - out mice have intact feeding -Stimulation insulin secretion despite marked impairment in their response to gloucose. J Biol Chem 277(40): 37176- 37183.

135. Seghers V, Nakazaki M, Demayo F, Aguilar Bryan L, Bryan J (2000) Sur 1 knock - out mice. A model for K (ATP) channel -independent regulation of insulin secretion. J Biol Chem 275(13): 9270-9277.

136. Koster JC, Remedi MS, Flagg TP, Johnson JD, Markova KP (2002) Hyperinsulinism induced by targated suppression of beta cells KATP channels. Proc Natl Acad Sci USA 99(26): 16992-16997. 


\section{Current Research in Diabetes \& Obesity Journal}

137. Remedi MS, Rochelcau JV, Tonga A, Patton BL, Mc Daniel ML (2006) Hyperinsulinism in mice with heterozygous loss of K(ATP)Channels. Diabetalogia 49(10): 2368-2378.

138. Defronzo RA, Bonadonna RC, Ferrunnini E (1992) Pathogenesis of NIDDM: A Balanced overview. Diabetes Care 15(3): 318-368.

139. Rifkin H (1991) Current status of non- insulin dependent diabetes mellitus (type II) : Management with gliclazide. Am J Med 90: 35-75.

140. Pearson ER, Starkey BJ, Powell RJ, Gribble FM, Clark PM (2003) Genetic cause of hyperglycemia and response to treatment of diabetes. Lancet 362(9392): 1275-1281.

141. Levetan C (2007) Oral antidiabetic agents in type 2 diabetes. Curr Med Res Opin 23(4): 945-952.

142. Groop LC, Pelkonen R, Koskimies S, Bottazzo G, Doniach D (1986) Secondary failure to treatment with oral antidiabetic agents in noninsulin - independent diabetes. Diabetes Care 9(2): 129-133.

143. Genuth S (1990) Insulin use in NIDDM Diabetes care 13(12):12401264.

144. Pontiroli AE, Calderara A, Pozza G (1994) Secondary failure of oral hypoglycaemis agents: frequency possible cause and management Diabetes Melab Rev 10(1): 31-43

145. Efanova IB, Zaitsev SV, Zhivotovsky B, Kohle M, Efendic S (1998) Glucose and tolbutamide induce apoptosis in pancreatic beta- cells A process depender on intracellular Ca2+ concentration. J Biol Chem 273(50): 33501- 33507.

146. Kawaki J, Nagashima K, Tanaka I, Miki T, Miyazaki M (1999) Unresponsiveness to glibenclamide during chronic treatment induced by reduction of ATP - sensitive $\mathrm{K}+$ channel activity. Diabetes 48(10): 2001-2006

147. Takahashi A, Nagashima K, Hamasaki A, Kuwamura N, Kawasaki Y (2007) Sulphonylurea and glinide reduce insulin content, functional expression of K (ATP) channels and accelerate apoptotic beta- cell deth in the chronic phase. Diabetes Res Clin Pract 77: 343-350.

148. Ball AJ, Mc Cluskey JT, Flatt PR, Mc Clenaghan N (2004) Chronic exposure to tolbutamide and glibenclamide impairs insulin secretion but not transcription of K+-ATP channel components. Pharmacol Res 50(1):41-46.

149. Hambrock A, De olivera Franz CB, Hiller S, Osswald H (2006) Glibenclamide - induced apoptosis is specifically enhanced by expression of the sulphonylurea receptor isoform SUR1 but not by expression of SUR2B or the mutant (M1289T). J Pharmacol Exp Ther 316(3): 1031-1037.

150. Haoyong Yu, Ruixia Li, Lei Zhang, Haibing Chen, Yugian Bao (2012) Clinical study: serum cA19-9 Levels Associated with metabolic control and Pancreatic Beta cell function in diabetic patients. Experimental Diabetes Research 2012: I D 745189 5. 143.

151. American Diabetes Association (2009) Medical management of hyperglycemia in type2 diabetes: A consensus algorithm for the initiation and adjustment of therapy. Diabetes Care 32(1): 193-203.

152. FDA (2011) Koro C, Barrett S, Oizilbash N (2007) Cancer risks in thiazolidinedione Drug Saf 16: 485-492.

153. Govindaraian R, Ratnasinghe J, Simmons DL, Siegel ER, Midathada MV, et al. (2007) Thiazolidinediones and risk of lung, prostate and colon cancer in patients with diabetes J Clin Oncol 25(12): 14761481.

154. Ramos - Nino ME, Maclean CD, Littenberg R (2007) Association between cancer prevalence and use of thiazolidinediones: results from the Vermont. Diabetes Information System B M C Med 5: 17.

155. Brun RP, Tontonoz P, Forman BM, Ellis R, Chen J (1996) Differential activate of adipogenesio by multiple PPAR isoforns. Genes Dev 10
974-984.

156. Petesen EF, Krssak M, Inzucchi S, Cline GW, Dufour S, Shulman GI (2000) Mechanism of troglitazone action in type 2 diabetes. Diabetes 49(5): 827-831.

157. Miyazaki Y, Mahankali A, Matsuda M, Mahankali S, Hardies J, et al (2002) Effect of pioglitazone on abdominal fat distribution and insulin sensitivity in type 2 diabetic patients. J Clin Endocrinol Metab 87(6): 2784-2791.

158. Bajaj M, Suraamornkul S, Pratipanawatr T, Hardies LJ, Pratipanawatr W, et al. (2003) Pioglitozone reduces hepatic fat content and augments splanchnic glucose uptake in patients with type 2 diabetes. Diabetes 52(6): 1364-1370.

159. Buchanan TA, Xiang AH, Peters RK, Kios SL, Marroquin A, et al. (2002) Preservation of pancreatic cell function and prevention of type 2 diabetes by pharmacological treatment of insulin resistance in high risk Hispanic women. Diabetes 51(9): 2796-2803.

160. Way IM, Harrington WW, Brown KK, Gottsechalk WK, Sundseth SS, et al. (2001) Comprehensive ribonucleic acid profiling reveals that peroxisome proliferation activated receptor activation has coordinate effects on gene expression in multiple insulin - sensitive tissue. Endocrinology 142(3): 1269-1277.

161. Alberktsen T, Frederiksen KS, Holnes WE, Boel E, Taylor K, et al. (2002) Novel genes regulate by the insulin sensitizer rosiglitazone during sadipocyte differentiation. Diabetes 51(4): 1042-1051.

162. Malerod L, Sporstol M, Juret LK, Mousavi A, Gjoen T (2003) Hepetic scavenger reseptor class B, type I is stimulated by peroxisome proliferator activated receptor and hepatocyte nuclear factor 4 Biochem Biophys Res Commun 305: 557-565.

163. Cha BS, Ciaraldi TP, Carter L, Nikoulina SE, Mudaliar S, et al. (2001) Peroxisome proliferator activated receptor (PPAR )and rectenoid X Receptor (RXR) agonists have complementary effects on glucose and lipid metabolism in human skeletal muscle. Diabetologia 44: 444452

164. Yoshimura R, Matsuyama M, Segama Y (2003) Expression of peroxisome proliferator - activated receptors (PPARs ) in human urinary bladder carcinoma and growth inhibition by its agonists. Int J Cancer 104(5) : 597-602.

165. Nakashiro KI, Hayashi Y, Kita A (2001) Role of peroxisomepraliferator activated receptor gamma and its ligands in nonneoplastic and neoplastic human urothelial cells. Am J Pathol 159(2): 591-597.

166. Guan YF, Zhang YH, Breyer RM, Davis L, Breyer MD (1999) Expression of peroxisome proliferator-activated receptor gamma (PPARgamma ) In human transitional bladder cancer and its role in including cell death. Neoplasia 1: 330-339.

167. Tontonoz P, Singer S, Forman BM (1997) Termi differentiation of human liposarcoma cells included by ligands for perxisome proliferator - activated receptor gamma and the retinoid X receptor Proc Natl Acad Sci USA 94(1):237-241.

168. Kubota T, Koshizuka K, Willisamsom KA (1998) Lig and for peroxisome proliferator - activated receptor gamma (troglitazone) has potent antitumor effect against - human prostate cancer both in vitro and in vivo. Cancer Res 58(15): 3344-3352.

169. Ohto K, Endi T, Haraguchi K, Hershman JM, Onaya T (2001) Ligands for peroxisome pralifer - activated receptor gamma inhibit growth and induce apoptosis of human papillary thyroid carcinoma cells J. Clin Endocrinol Metab 86: 2170-2177.

170. Elstner E, Muller C, Koshizuka K (1998) Ligands for peroxisome proliferator activated receptor gamma and retinoic acid receptor inhibit growth and induce apoptosis of human breast cancer cells in vitro and in BNX Mice. Proc. Natl Acad Sci USA 95(15): 8806-8811. 


\section{Current Research in Diabetes \& Obesity Journal}

171. Takeda Pharmaceuticals America (2009) Inc. Actos (Pioglitazone Hydrochoride) Tablets Full Prescribing information.

172. Newman DJ, Cragg GM, Sander KM (2003) Natural products as sources of new drugs over the period 1981-2002. J Nat Prod 66(7): 1022-1037.

173. Butler MS (2004) The role of natural product chemistry in drug discovery. J Nat Prod 67: 2141-2153.

174. Balunas MJ, Kinghorn AD (2005) Drug discovery from medicinal plants. Life Sci 78: 431-441.

175. Gurib-Fakim A (2006) Medicinal Plants: Traditions of yesterday and drugs of tomorrow. Mol Aspects Med 27: 1-93.

176. Newman DJ, Cragg GM (2007) Natural products as sources of new drugs over the last 25 years. J Nat Prod 70: 461-477.

177. Joel Fuhrman Nutrient Density and phytochemical rich food.

178. Modak M, Dixit P, Londhe I, Ghaskadi S, Devasagagam TPA (2007) Indian herbs and herbal drug used for the treatment of diabetes. J Clin Biochem Nutr 40(3): 163-173.

179. Sarita G, Kadam DB, Pawar PS (2007) Study report of use of Madhusar. -Role of Ayurvedic treatment in controlling diabetes- An Ayurvedic Medicine.
180. Kumar S, Shachi K, Dubey NK (2013) The therapeutic efficacy of Coccinia indica herbs on blood glucose levels in allokan induced diabetes albino rats. Proceeding of Inte. Conf. on 1CGSTSMAAE pp. 403-404.

181. The ORIGIN Trial (2010) Outcome Reduction with Initial Glargine Intervention. ORIGIN Basal Insulin.

182. James D Lewis, Assiamira Ferrare, Tiffany Peng, Monique Hedderson, Warren B Bilker, et al. (2011) Risk of Bladder cancer among Diabetic patients treated with pioglitazone interim report of a longitudinal Cohort study. Diabetes Care 24(4): 916-922.

183. National diabetes Fact Sheet: General Information and national Estimates on Diaberes in the United Stats, 2007 (2008) [article online], Allanta, Georgia, centres for Disease contact and prevention.

184. Call EE, Kaaks R (2004) Overweight, obesity and cancer epidemiological evidence and proposed mechanisms. Nature Reviews cancer 4(8): 579-591.

185. Uli T, Slattengreen A, Redmer I, Counts H, Eglash A, Schrager S (2011) Obesity and women's health: an evidence-based review. J Am Board Fam Med 24(1): 75-85.

Your next submission with Juniper Publishers
will reach you the below assets
- Quality Editorial service
- Swift Peer Review
- Reprints availability
- E-prints Service
- Manuscript Podcast for convenient understanding
- Global attainment for your research
- Manuscript accessibility in different formats
( Pdf, E-pub, Full Text, Audio)
- Unceasing customer service
Track the below URL for one-step submission
https://juniperpublishers.com/online-submission.php

